\title{
Clinical and Pathological Evaluation of Benign Skin Lesions
}

(Penilaian Klinikal dan Patologi Lesi Kulit Benigna)

\author{
SABAHATTIN DESTEK* \& VAHIT ONUR GUL
}

\begin{abstract}
Skin lesions are commonly benign in nature. The present study aims to evaluate the prevalence and clinicopathological characteristics of a large series of benign skin lesions (BSLS) excised in our clinic. Patients with skin lesions who underwent total excisional biopsy at the general surgery clinic between 2012 and 2016 were reviewed. A total of 551 patients with BSLs were included in the study. Of these, $43.7 \%$ were females and $56.7 \%$ were males. The age range was between 2 and 98 years with a mean of 39.7 years. The most commonly occurring group of BSLs was of the appendageal tumors $(33.3 \%)$, and this finding was statistically significant. The most common keratinocytic BSL (13.6\%) was verruca vulgaris. In the present study, various types of BSLs and their occurrences were evaluated. Benign skin tumors can turn into malignant types. A biopsy should be performed to establish the exact diagnosis. We performed an excisional biopsy to confirm the diagnosis.
\end{abstract}

Keywords: Benign skin lesions; clinicopathological examination; excisional biopsy

\section{ABSTRAK}

Lesi kulit adalah perkara biasa dan kebanyakannya lesi jinak. Tujuan kajian ini adalah untuk menilai kelaziman dan ciri klinikopatologi siri besar lesi kulit benigna yang dikeluarkan di klinik kami. Pesakit yang mengalami lesi kulit dikaji semula, yang menjalani jumlah biopsi ekslusif dalam klinik pembedahan umum antara 2012 dan 2016. Sejumlah 551 pesakit dengan lesi kulit benigna termasuk dalam kajian ini. Daripada pesakit ini, $43.7 \%$ adalah wanita dan $56.7 \%$ adalah lelaki. Julat umur adalah antara 2 dan 98 tahun dengan purata 39.7 tahun. Kumpulan yang paling biasa (33.3\%) lesi kulit jinak adalah tumor lampiran dan penemuan ini secara statistik secara signifikan. Lesi kulit yang paling biasa $(13.6 \%)$ adalah verruca vulgaris. Dalam kajian ini, pelbagai jenis lesi kulit benigna dan frekuensi relatifnya dinilai. Tumor kulit benigna boleh berubah menjadi jenis malignan. Biopsi perlu diambil untuk menentukan diagnosis yang tepat. Kami melakukan biopsi pengecualian untuk diagnosis.

Kata kunci: Biopsi eksisi; lesi kulit benigna; pemeriksaan klinikopatologi

\section{INTRODUCTION}

The vast majority of skin lesions are benign (Nguyen \& Zuniga 2013). A benign skin lesion (BSL) does not spread to other parts of the body but continues its growth at the location of its origin (Higgins et al. 2015; Ingraffea 2013). Premalignant skin lesions (PSLs) can transform into malignant tumors at a rate of $10 \%$ (Freak 2005; Ingraffea 2013). They are most commonly seen in males (Higgins et al. 2015; Ingraffea 2013). The lifetime risk of skin cancer development has been reported in one out of five people in the United States (Freak 2005; Higgins et al. 2015; Ingraffea 2013).

Skin lesions are usually sporadic; however, they can also be a symptom of a syndrome, or they may be associated with systemic malignancies (Ingraffea 2013; Nguyen \& Zuniga 2013). Therefore, clinicians should differentiate benign from malignant lesions and should follow a systematic approach in evaluating these lesions (Gogi \& Ramanujam 2013). If there is a clinical suspicion of malignancy, biopsy should definitely be performed (Woon \& Serpell 2008).
Along with the reported findings in the literature, the present study aims to review and evaluate the prevalence and clinicopathological features of the BSLs that are surgically excised in our clinic. Patients with skin lesions who underwent total excisional biopsy at the general surgery department between 2012 and 2016 were reviewed. The histopathological diagnoses of these lesions were examined to determine whether they were associated with the tumor size, location, and number and whether they were associated with the age and gender.

\section{MATERIALS AND METHODS}

The present study included patients with skin lesions treated in our general surgery clinic between 2012 and 2016. Patients were followed up for recurrence for a mean period of 2 years. The patients' charts showed that a total of 712 patients underwent excisional biopsy due to several types of skin lesions (Edlich et al. 2004). Of these, 27 patients were diagnosed with nonspecific skin lesions and 136 were diagnosed with malignant skin lesions (MSLs). 
Ultrasonography, computed tomography, or magnetic resonance imaging was performed for patients with skin lesions before biopsy, depending on physical examination findings of the size and appearance of the lesion. Fineneedle, tru-cut, or excisional biopsy was performed for diagnosis. Patients with nonspecific skin lesions and MSLS were excluded from the study. Of those who were diagnosed with a MSL through pathological examination, nine had been prediagnosed with BSL after the physical examination; however, the excisional biopsy result was reported to confirm malignant lesion.

A total of 551 patients with BSLs were included in the study. Patients with BSLs were evaluated. Patients undergoing follow-up or tru-cut biopsy, those who were not followed up, those without excisional biopsy, and those whose data were not accessible were excluded from the study. Patients undergoing fine-needle biopsy and tru-cut biopsy for the diagnosis of BLS (14 patients) were excluded from the study because of their small number. Patients undergoing excisional biopsy and those whose data were accessible were included in the study.
The lesion size, number of lesions, and morphology were not limited.

The age and gender of patients as well as the number, size in millimeter ( $\mathrm{mm})$, anatomical location, and histopathological diagnosis of the skin lesions were evaluated. They were categorized into 0-14, 15-59, and $\geq 60$ age groups based on other scientific studies (Murray et al. 2007).

In the present study, BSLs were categorized and listed according to the World Health Organization histological classification (LeBoit et al. 2006). Accordingly, they were categorized into six main groups and examined. These main groups were keratinocytic, melanocytic, appendageal, hematolymphoid, soft tissue, and neural BSLs. The lesions included in these main groups were examined (Table 1).

\section{STATISTICAL ANALYSES}

The data obtained from the present study were analyzed using IBM SPSS Statistics Version 22 package software. Shapiro-Wilk test was performed to determine normal

TABLE 1. Benign skin lesions subtypes

\begin{tabular}{|c|c|c|c|}
\hline \multirow[t]{2}{*}{ Benign skin lesions } & & \multicolumn{2}{|c|}{ Number of lesions } \\
\hline & & $\mathrm{n}$ & $\%$ \\
\hline Keratinocytic & $\begin{array}{l}\text { Verruca vulgaris } \\
\text { Verruca plantaris } \\
\text { Seborrheic keratosis } \\
\text { Keratoacanthoma } \\
\text { Lichen planus-like keratosis }\end{array}$ & $\begin{array}{c}75 \\
29 \\
27 \\
5 \\
5\end{array}$ & $\begin{array}{l}53.19 \\
20.57 \\
19.15 \\
3.55 \\
3.55\end{array}$ \\
\hline Melanocytic & $\begin{array}{l}\text { Melanocytic nevi } \\
\text { Combined nevus }\end{array}$ & $\begin{array}{l}55 \\
16\end{array}$ & $\begin{array}{l}77.46 \\
22.54\end{array}$ \\
\hline Appendageal & $\begin{array}{l}\text { Hidrocystoma } \\
\text { Cystic sebaceous tumor } \\
\text { Chondroid syringoma } \\
\text { Hidradenoma } \\
\text { Pilomatricoma } \\
\text { Trichoblastoma } \\
\text { Trichilemmoma } \\
\text { Sebaceoma }\end{array}$ & $\begin{array}{c}1 \\
144 \\
2 \\
2 \\
8 \\
1 \\
24 \\
2\end{array}$ & $\begin{array}{c}0.54 \\
78.26 \\
1.09 \\
1.09 \\
4.35 \\
0.54 \\
13.04 \\
1.09\end{array}$ \\
\hline Hemato-lymphoid & $\begin{array}{l}\text { Lymphomatoid granulomatosis } \\
\text { Juvenile xanthogranuloma }\end{array}$ & $\begin{array}{l}3 \\
2\end{array}$ & $\begin{array}{l}60 \\
40\end{array}$ \\
\hline Soft tissue & $\begin{array}{l}\text { Dermatofibroma } \\
\text { Cherry hemangioma } \\
\text { Pyogenic granuloma } \\
\text { Cavernous hemangioma } \\
\text { Arteriovenous hemangioma } \\
\text { Lymphangioma circumscriptum } \\
\text { Digital fibrokeratoma } \\
\text { Dermatomyofibroma } \\
\text { Lipoma } \\
\text { Digital mucous cyst } \\
\text { Keloid scar } \\
\text { Hypertrophic scar }\end{array}$ & $\begin{array}{c}33 \\
15 \\
19 \\
2 \\
3 \\
2 \\
4 \\
3 \\
41 \\
1 \\
17 \\
5\end{array}$ & $\begin{array}{c}22.76 \\
10.34 \\
13.1 \\
1.38 \\
2.07 \\
1.38 \\
2.76 \\
2.07 \\
28.28 \\
0.69 \\
11.72 \\
3.45\end{array}$ \\
\hline Neural & $\begin{array}{l}\text { Neurothekeoma } \\
\text { Neuroma } \\
\text { Granular cell tumor }\end{array}$ & $\begin{array}{l}3 \\
1 \\
1\end{array}$ & $\begin{array}{l}60 \\
20 \\
20\end{array}$ \\
\hline
\end{tabular}


distribution of the variables. In interpreting the results, if $\mathrm{p}$ value was greater than 0.05 , it was considered that the variables came from the normal distribution; if $p$ value was less than 0.05 , it was considered that the variables did not come from the normal distribution. The Mann-Whitney U and Kruskal-Wallis H tests were used to examine the differences between the groups as the variables were not normally distributed. The Chi-square $\left(\chi^{2}\right)$ analysis was used to analyze the associations between the groups of nominal variables. Fisher's exact test was used when the expected values in the cells of the $2 \times 2$ tables did not achieve a sufficient size. The significance level of 0.05 was used to interpret the results. A p value less than 0.05 indicated a significant association, whereas $\mathrm{p}$ values greater than 0.05 indicated that there was no significant association.

\section{RESULTS}

The present study included a total of 551 patients. The majority of patients $(56.2 \%, \mathrm{n}=310)$ were males, and the study population had a female:male ratio of $241 / 310$ (0.77). The age of patients in the study ranged from 2 to 98 years, and the mean age was 39.7 years. The most common $(18.8 \%, \mathrm{n}=104)$ accompanying disease group were hepatobiliary disorders (fatty liver and gall bladder stone). BSLs were most commonly located in the head and neck region $(43.1 \%, \mathrm{n}=239)$. The lesions were mostly single $(82.5 \%, \mathrm{n}=455)$ with a mean diameter of 14.1 $\mathrm{mm}$. The success rate of excisional biopsy diagnosis was $100 \%(\mathrm{n}=551)$. The mean follow-up period was 2 years The rate of local recurrence was $2.3 \%(n=13)$ (Table 2).
A statistically significant difference between the gender and the BSL groups $(\mathrm{p}=0.001)$ was observed. Appendageal BSLS were present in $29.05 \%(\mathrm{n}=70)$ of females and in $36.77 \%(\mathrm{n}=114)$ of males. Soft tissue BSLs were present in $21.58 \%(n=52)$ of females and in $30 \%(n=93)$ of males. Keratinocytic BSLs were present in $26.14 \%(n=63)$ of females and in $25.16 \%(n=78)$ of males. Melanocytic BSLS were present in $21.58 \%(n=52)$ of females and in $6.13 \%$ $(\mathrm{n}=18)$ of males. Hematolymphoid BSLs were present in $1.24 \%(n=3)$ of females and in $0.65 \%(n=2)$ of males. Neural BSLs were present in $0.41 \%(n=1)$ of females and in $1.29 \%(n=4)$ of males (Table 3$)$.

In the present study, a statistically significant association between the BSL groups and the age distribution $(\mathrm{p}=0.008)$ was observed. In the $0-14$ age group, $2.94 \%(n=1)$ of patients had appendageal BSLs. This was $35.23 \%(\mathrm{n}=155)$ in the 15-59 age group, and $36.36 \%(\mathrm{n}=36)$ in the 60 and above age group. Soft tissue BSLS were present in $35.29 \%$ ( $n$ $=12$ ) of patients in the 0-14 age group. Additionally, these types of skin lesions were present in $27.05 \%(n=119)$ in the $15-59$ age group and in $18.18 \%(n=14)$ in the 60 and above age group. Keratinocytic BSLs were present in $41.18 \%$ ( $n=$ 14) of patients in the $0-14$ age group, in $22.5 \%(\mathrm{n}=99)$ in the $15-59$ age group, and in $36.36 \%(n=28)$ in the 60 and above age group. Melanocytic BSLs were present in $14.71 \%$ $(\mathrm{n}=5)$ of patients in the $0-14$ age group, in $13.41 \%(\mathrm{n}=$ $59)$ in the $15-59$ age group, and in $9.09 \%(n=7)$ in the 60 and above age group. Hematolymphoid BSLs were present in $2.94 \%(\mathrm{n}=1)$ of patients in the $0-14$ age group and in $0.91 \%(\mathrm{n}=4)$ in the $15-59$ age group. Neural BSLs were present in $2.94 \%(n=1)$ of patients in the $0-14$ age group and in $0.91 \%(n=4)$ in the $15-59$ age group (Table 3$)$.

TABLE 2. Demographic and clinical characteristics of subjects

\begin{tabular}{ll}
\hline Demographic and clinical features & Distribution of properties \\
\hline Gender (Female/Male) & $241 / 310(0.77)$ \\
Age & $2-98($ mean 39.7) years \\
Age distribution & $0-14(6.1 \%, \mathrm{n}=34)$ \\
& $15-59(79.8 \%, \mathrm{n}=440)$ \\
& $\geq 60(13.9 \%, \mathrm{n}=77)$ \\
Comorbidities & Hepatobiliary disease $(18.8 \%, \mathrm{n}=104)$ \\
& Renal disease $(12.5 \%, \mathrm{n}=69)$ \\
& Endocrine diseases $(7 \%, \mathrm{n}=39)$ \\
& Vascular disease $(6.2 \%, \mathrm{n}=34)$ \\
& Gynecological disease $(2.3 \%, \mathrm{n}=13)$ \\
The main complaint & Painless swelling $(90 \%, \mathrm{n}=496)$ \\
& Color change $(32 \%, \mathrm{n}=176)$ \\
Lesion localization & Head and neck $(43.4 \%, \mathrm{n}=239)$ \\
& Trunk $(25.9 \%, \mathrm{n}=143)$ \\
& Upper extremities $(13.7 \%, \mathrm{n}=76)$ \\
& Lower extremities $(17.0 \%, \mathrm{n}=94)$ \\
Number of lesions & Single $(82.5 \%, \mathrm{n}=455)$ \\
Lesion diameter & Multiple $(17.4 \%, \mathrm{n}=96)$ \\
& $1-70($ mean 14.1$) \mathrm{mm}$ \\
\hline &
\end{tabular}


There was a statistically significant relationship between the original localization of the tumor and the BSL groups ( $\mathrm{p}=0.001)$. Appendageal BSLs comprised $36.55 \%$ $(\mathrm{n}=87)$ of the neoplasms originating from the head and neck region, $48.95 \%(\mathrm{n}=70)$ of the neoplasms originating from the trunk, $26.32 \%(n=20)$ from tumors of the upper extremities, and $7.45 \%(n=7)$ from tumors of the lower extremities. Soft tissue BSLS comprised $15.55 \%(n=37)$ of the neoplasms originating from the head and neck region, $30.07 \%(n=43)$ from the trunk, $47.37 \%(n=36)$ from the upper extremities, and $30.85 \%(n=29)$ from the lower extremities. Keratinocytic BSLs comprised $21.85 \%$ ( $\mathrm{n}=$ 52 ) of the neoplasms originating from the head and neck region, $18.42 \%(n=20)$ from the trunk, $18.42 \%(n=14)$ from the upper extremities, and $58.51 \%(\mathrm{n}=55)$ from the lower extremities. Melanocytic BSLs comprised $23.95 \%$ (n $=57$ ) of the neoplasms originating from the head and neck region, $6.29 \%(\mathrm{n}=9)$ from the trunk, 3.95\% $(\mathrm{n}=3)$ from the upper extremities, and $2.13 \%(\mathrm{n}=2)$ from the lower extremities. Hematolymphoid BSLs comprised $0.42 \%$ (n $=1$ ) of the neoplasms originating from the head and neck region, $0.7 \%(n=1)$ from the trunk, and $3.95 \%(n=3)$ from the upper extremities. Neural BSLs comprised $1.68 \%$ $(n=4)$ of the tumors originating from the head and neck region and $1.06 \%(n=1)$ of the tumors originating from the lower extremities (Table 3 ).

There was a statistically significant difference between the number of the lesions and the BSL groups (p $=0.001)$. Appendageal BSLs comprised $35.82 \%(n=163)$ of the single lesions and $21.88 \%(\mathrm{n}=21)$ of the multiple lesions. Soft tissue BSLS comprised $28.13 \%(n=128)$ of the single lesions and $17.71 \%(n=17)$ of the multiple lesions. Keratinocytic BSLs comprised $23.3 \%(\mathrm{n}=106)$ of the single lesions and $36.46 \%(n=35)$ of the multiple lesions. Melanocytic BSLS comprised $10.55 \%(\mathrm{n}=48)$ of the single lesions and $23.96 \%(n=23)$ of the multiple lesions. Hematolymphoid BSLS comprised $1.1 \%(n=5)$ of the single lesions. A total of $1.1 \%$ of the single lesions was considered as neural BSLS.

There were statistically significant differences between BSL groups in terms of the diameters of the lesions ( $p=$ $0.001)$. The mean diameters of the lesions were 17.33 $(\mathrm{n}=184)$ for appendageal BSLs, $15.8 \mathrm{~mm}(\mathrm{n}=5)$ for neural BSLs, $15.66 \mathrm{~mm}(\mathrm{n}=145)$ for soft tissue BSLs, $11.26 \mathrm{~mm}(\mathrm{n}=141)$ for keratinocytic BSLs, $9.2 \mathrm{~mm}(\mathrm{n}=$ 5) for hematolymphoid BSLs, and $8.73 \mathrm{~mm}(\mathrm{n}=71)$ for

TABLE 3. The relationship between gender, age, number of lesions, and localization of benign skin lesions

\begin{tabular}{|c|c|c|c|c|c|c|c|c|c|}
\hline \multirow[t]{3}{*}{ Benign skin lesions } & \multicolumn{8}{|c|}{ Gender } & \multirow{3}{*}{$\begin{array}{c}\text { Chi-square Test } \\
\mathrm{p}\end{array}$} \\
\hline & \multicolumn{4}{|c|}{ Female } & \multicolumn{4}{|c|}{ Male } & \\
\hline & $\mathrm{n}$ & & $\%$ & & 1 & \multicolumn{3}{|c|}{$\%$} & \\
\hline Keratinocytic & 63 & & 26.14 & & 7 & \multicolumn{3}{|c|}{25.16} & \multirow{6}{*}{0.001} \\
\hline Melanocytic & 52 & & 21.58 & & 1 & \multicolumn{3}{|c|}{6.13} & \\
\hline Appendageal & 70 & & 29.05 & & 1 & \multicolumn{3}{|c|}{36.77} & \\
\hline Haematolymphoid & 3 & & 1.24 & & 2 & & 0.65 & & \\
\hline Soft tissue & 52 & & 21.58 & & 9 & & 30 & & \\
\hline \multirow[t]{4}{*}{ Neural } & 1 & & 0.41 & & 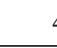 & & 1.29 & & \\
\hline & \multicolumn{8}{|c|}{ Age groups } & \multirow[t]{2}{*}{ Chi-square Test } \\
\hline & \multicolumn{2}{|c|}{ 0-14 Years } & & \multicolumn{2}{|c|}{$15-59$ years } & \multicolumn{3}{|c|}{$\geq 60$ years } & \\
\hline & $\mathrm{n}$ & \multicolumn{2}{|l|}{$\%$} & $\mathrm{n}$ & $\%$ & $\mathrm{n}$ & \multicolumn{2}{|r|}{$\%$} & $\mathrm{p}$ \\
\hline Keratinocytic & 14 & \multicolumn{2}{|l|}{41.18} & 99 & 22 & 28 & \multicolumn{2}{|c|}{36.36} & \multirow{6}{*}{0.008} \\
\hline Melanocytic & 5 & \multicolumn{2}{|l|}{14.71} & 59 & 13 & 7 & \multicolumn{2}{|c|}{9.09} & \\
\hline Appendageal & 1 & \multicolumn{2}{|l|}{2.94} & 155 & 35 & 28 & & 36.36 & \\
\hline Haematolymphoid & 1 & 2.94 & & 4 & 0. & 0 & & 0 & \\
\hline Soft tissue & 12 & 35.29 & & 119 & 27 & 14 & & 18.18 & \\
\hline \multirow[t]{4}{*}{ Neural } & 1 & 2.94 & & 4 & 0. & 0 & & 0 & \\
\hline & \multicolumn{8}{|c|}{ Localization } & \multirow[t]{2}{*}{ Chi-square Test } \\
\hline & \multicolumn{2}{|c|}{ Head and neck } & \multicolumn{2}{|c|}{ Trunk } & \multicolumn{2}{|c|}{ Upper extremity } & \multicolumn{2}{|c|}{$\begin{array}{c}\text { Lower } \\
\text { extremity }\end{array}$} & \\
\hline & $\mathrm{n}$ & $\%$ & $\mathrm{n}$ & $\%$ & $\mathrm{n}$ & $\%$ & $\mathrm{n}$ & $\%$ & $\mathrm{p}$ \\
\hline Keratinocytic & 52 & 21.85 & 20 & 13.99 & 14 & 18.42 & 55 & 58.51 & \\
\hline Melanocytic & 57 & 23.95 & 9 & 6.29 & 3 & 3.95 & 2 & 2.13 & \\
\hline Appendageal & 87 & 36.55 & 70 & 48.95 & 20 & 26.32 & 7 & 7.45 & \\
\hline Haematolymphoid & 1 & 0.42 & 1 & 0.7 & 3 & 3.95 & 0 & 0 & 0.001 \\
\hline Soft tissue & 37 & 15.55 & 43 & 30.07 & 36 & 47.37 & 29 & 30.85 & \\
\hline Neural & 4 & 1.68 & 0 & 0 & 0 & 0 & 1 & 1.06 & \\
\hline
\end{tabular}


TABLE 4. The relationship between number of lesions and diameter of benign skin lesions

\begin{tabular}{|c|c|c|c|c|c|c|}
\hline \multirow{3}{*}{ Benign skin lesions } & \multicolumn{5}{|c|}{ Number of lesions } & \multirow{3}{*}{$\begin{array}{c}\text { Chi-square Test } \\
\mathrm{p}\end{array}$} \\
\hline & \multicolumn{2}{|c|}{ Single } & & \multicolumn{2}{|c|}{ Multiple } & \\
\hline & $\mathrm{n}$ & $\%$ & & $\mathrm{n}$ & $\%$ & \\
\hline Keratinocytic & 106 & 23.3 & & 35 & 36.46 & \\
\hline Melanocytic & 48 & 10.55 & & 23 & 23.96 & \\
\hline Appendageal & 163 & 35.82 & & 21 & 21.88 & \\
\hline Hematolymphoid & 5 & 1.1 & & 0 & 0 & 0.001 \\
\hline Soft tissue & 128 & 28.13 & & 17 & 17.71 & \\
\hline \multirow[t]{3}{*}{ Neural } & 5 & 1.1 & & 0 & 0 & \\
\hline & \multicolumn{5}{|c|}{ Lesion diameter $(\mathrm{mm})$} & Kruskal-Wallis Test \\
\hline & $\mathrm{n}$ & Mean & Min & $\operatorname{Max}$ & SD & $\mathrm{p}$ \\
\hline Keratinocytic & 141 & 11.26 & 1 & 35 & 7.19 & \multirow{6}{*}{0.001} \\
\hline Melanocytic & 71 & 8.73 & 2 & 50 & 6.2 & \\
\hline Appendageal & 184 & 17.33 & 3 & 55 & 9.68 & \\
\hline Hematolymphoid & 5 & 9.2 & 3 & 16 & 5.81 & \\
\hline Soft tissue & 145 & 15.66 & 2 & 70 & 13.22 & \\
\hline Neural & 5 & 15.8 & 6 & 35 & 11.92 & \\
\hline
\end{tabular}

neural BSLs. The lesion diameter of the melanocytic BSLS was significantly lower compared with that of the main groups of appendageal and soft tissue BSLs. The lesion diameter of the keratinocytic BSLs and soft tissue BSLS were significantly lower than that of the appendageal BSLS (Table 4).

\section{DISCUSSION}

The epidemiological studies on skin diseases have reported the rates of BSL and MSL at 4.5-12\% and 1.56\%, respectively (Bertanha et al. 2006; Furue et al. 2011; Mohammedamin et al. 2006). In general, the ratio of BSLS to the malignant ones is 1.5 or 4.5 (Bertanha et al. 2006; Furue et al. 2011; Kartal et al. 2015; Mohammedamin et al. 2006). Recent studies have reported a tendency of PSLs to increase over the last years, with rates $1.82 \%-4 \%$ found in large-scale epidemiological studies (Bas et al. 2014; Choi et al. 2016; Kim et al. 2010).

In various studies, BSLs were mostly seen in women (53.7\%-63.2\%) (Bertanha et al. 2016; Sinikumpu et al. 2014). In the present study, $56 \%(\mathrm{n}=310)$ of all BSLs were found in males, and $47.7 \%(n=241)$ were found in females. In several epidemiological studies conducted in various countries, the most common type of BSL in females and males is keratinocytic BSLs (Furue et al. 2011; Kartal et al. 2015; Mohammedamin et al. 2006). In the present study, appendageal BSLs was the most common type found in females and males.

In various studies, $55 \%-60 \%$ of BSLs were seen in the 15-59 age group (Furue et al. 2011; Sinikumpu et al. 2014). In the present study, $79.85 \%(n=440)$ of all BSLs were seen in the 15-59 age group. The most common BSL type among children, adolescents, middle-aged, and elderly people has been reported to be keratinocytic BSL based on epidemiological studies on skin diseases (Kyriakis et al.
2012; Sinikumpu et al. 2014). In the present study, the most common types of BSL in the 0-14 and 15-59 age groups are keratinocytic and appendageal BSLs, respectively; overall, keratinocytic and appendageal BSLs are the most common BSL types.

In some studies, BSLs have been reported to be more common in the head and neck regions, and in some studies they have been reported to be more common in the truncal region (Gogi \& Ramanujam 2013; Pujani et al. 2016). In the present study, $43.19 \%(n=238)$ of BSLs were localized in the head and neck region. The BSL diameters reported in the studies are usually less than $25 \mathrm{~mm}$ (Furue et al. 2011; Pujani et al.2016). In the present study, the lesion diameter of BSLs was between 1 and $70 \mathrm{~mm}$, and the mean was 14.1 $\mathrm{mm}$. Appendageal BSLs were found to be the largest lesions with a mean diameter of $17.33 \mathrm{~mm}$. BSLs reported in the literature are generally singular (Ferrándiz et al. 2017; Pujani et al. 2016). In the present study, $82.57 \%(n=455)$ of BSLs were single lesions.

BSLs can accompany some systemic diseases (Nguyen \& Zuniga 2013). An underlying systemic disease should be investigated especially in the presence of multiple lesions. In the presence of multiple seborrheic keratosis (SK); trichilemmoma; or cystic sebaceous tumors (CSTs), malignancies of the internal organs, such as the stomach, colon, or the pancreas, should be suspected (Gogi \& Ramanujam 2013; Kanitakis 2010; Luba et al. 2003). The incidences of CSTs, keratoacanthoma, and sebaceoma increase in Muir-Torre syndrome; the incidences of hemangioma, lipoma, and trichilemmoma increase in Cowden's disease; the incidence of CST increases in Gardner syndrome (Gogi \& Ramanujam 2013; Luba et al. 2003). However, we did not observe any of these conditions in the present study.

Several studies have demonstrated that some BSLS may develop into malignant tumors (Lee 2010). It has 
been reported that basal cell carcinoma may develop from SK; squamous cell carcinoma may develop from verruca vulgaris or keratoacanthoma lesions; melanoma may develop from melanocytic nevi (Gogi \& Ramanujam 2013). None of these conditions were found in the present study. Malignant lesions can be misdiagnosed as benign (Lee 2010). In the present study, although the physical examination findings of nine patients were like BSL, the pathological examination confirmed MSL. These patients accounted for $1.6 \%$ of MSL patients. For this reason, biopsy should be taken to confirm the diagnosis (Ferrándiz et al. 2017).

Several studies recommend fine-needle aspiration, core, or excisional biopsy to be performed, allowing for a definite diagnosis to be made so that the tumor structure and histological type can be identified, and its grade can be determined (Ferrándiz et al. 2017; Hwang et al. 2016). Studies report that the core biopsy is superior to the fine-needle aspiration biopsy and excisional biopsy is superior to core biopsy in terms of sensitivity, specificity, predictive value, and accuracy (Wakely \& Kneisl 2000; Woon \& Serpell 2008). It has been reported that the overall diagnostic accuracy of the excisional biopsy may be as high as $98 \%$ (Kasraeian et al. 2010).

In the present study, an excisional biopsy was performed that preserved the healthy margins $(>1 \mathrm{~mm})$ for all lesions prediagnosed as BSL. The diagnostic accuracy was found to be $100 \%$. Several studies have reported that there might be recurrences in the lesions after the excisional biopsies at varying rates ranging from $2 \%-5 \%$ (Layfield et al. 2014). The recurrence rate after excisional biopsy was $2.3 \%$ in the present study, and surgical excision was repeated in these patients (Kasraeian et al. 2010; Layfield et al.2014). Excisional biopsy was successful in the diagnosis and treatment of patients.

\section{CONCLUSION}

In the present study, we evaluated the clinical profile and different types of BSLs in terms of age, gender, and area distribution. Some BSLS may be associated with systemic diseases or malignancies. BSLs may also develop into a malignant tumor. Therefore, clinicians should follow a systematic approach to BSLs. Sometimes, the diagnosis of skin neoplasias cannot be made based on their clinical characteristics solely. Hence, a pathological examination should be performed. As in the present study, excisional biopsy can be performed successfully for both diagnosis and treatment.

\section{REFERENCES}

Bas, Y., Kalkan, G., Seckin, H.Y., Takcı, Z., Sahin, S. \& Demir, A.K. 2014. Analysis of dermatologic problems in geriatric patients. Turkish Journal of Dermatology 8(4): 206-209.

Bertanha, F., Nelumba, E.J., Freiberg, A.K., Samorano, L.P. \& Neto, F.C. 2016. Profile of patients admitted to a triage dermatology clinic at a tertiary hospital in São Paulo, Brazil. Anais brasileiros de dermatologia 91(3): 318-325.
Choi, S.H., Kim, K.H. \& Song, K.H. 2016. Clinical features of cutaneous premalignant lesions in Busan City and the Eastern Gyeongnam Province, Korea: A retrospective review of 1,292Cases over 19 Years (1995 2013). Annals of Dermatology 28(2): 172-178.

Edlich, R.F., Becker, D.G., Long, W.B. \& Masterson, T.M. 2004. Excisional biopsy of skin tumors. Journal of Long-Term Effects of Medical Implants 14(3): 201-214.

Ferrándiz, C., Malvehy, J., Guillén, C., Ferrándiz-Pulido, C. \& Fernández-Figueras, M. 2017.Precancerous skin lesions. Actas Dermo-Sifiliográficas 108(1): 31-41.

Freak, J. 2005. Identification of skin cancers 1: Benign and premalignant lesions. British Journal of Community Nursing 10(1): 8-12.

Furue, M., Yamazaki, S., Jimbow, K., Tsuchida, T., Amagai, M., Tanaka, T., Matsunaga, K., Muto, M., Morita, E., Akiyama, M., Soma, Y., Terui, T. \& Manabe, M. 2011. Prevalence of dermatological disorders in Japan: a nationwide, crosssectional, seasonal, multicenter, hospital-based study. The Journal of Dermatology 38(4): 310-320.

Gogi, A.M. \& Ramanujam, R. 2013. Clinicopathological study and management of peripheral soft tissue tumours. Journal of Clinical and Diagnostic Research 7(11): 2524-2526.

Higgins, J.C., Maher, M.H. \& Douglas, M.S. 2015. Diagnosing common benign skin tumors. American Family Physician 92(7): 601-607.

Hwang, S-M., Pan, H-C., Hwang, M-K., Kim, M-W. \& Lee, J-S. 2016. Malignant skin tumor misdiagnosed as a benign skin lesion. Archives of Craniofacial Surgery 17(2): 86-89.

Ingraffea, A. 2013. Benign skin lesions. Facial Plastic Surgery Clinics of North America 21(1): 21-32.

Kanitakis, J. 2010. Adnexal tumours of the skin as markers of cancer-prone syndromes. Journal of the European Academy of Dermatology and Venereology 24(4): 379-387.

Kartal, D., Cinar, S.L., Akin, S., Ferahbas, A. \& Borlu, M. 2015. Skin findings of geriatric patients in Turkey: A 5-year survey. Dermatol Sinica 33(4): 196-200.

Kasraeian, S., Allison, D.C., Ahlmann, E.R., Fedenko, A.N. \& Menendez, L.R. 2010. A Comparison of fine-needle aspiration, core biopsy, and surgical biopsy in the diagnosis of extremity soft tissue masses. Clinical Orthopaedics and Related Research 468(11): 2992-3002.

Kim, H.S., Cho, E.A., Bae, J.M., Yu, D.S., Oh, S.T., Kang, H., Park, C.J., Lee, J.D., Lee, J.Y.,Kim, S.Y., Kim, H.O. \& Park, Y.M. 2010. Recent trend in the incidence of premalignant and malignant skin lesions in Korea between 1991 and 2006. Journal of Korean Medical Science 25(6): 924-929.

Kyriakis, K.P., Alexoudi, I., Askoxylaki, K., Vrani, F. \& Kosma, E. 2012. Epidemiologic aspects of seborrheic keratoses. International Journal of Dermatology 51(2): 233-234.

Layfield, L.J., Schmidt, R.L., Sangle, N. \& Crim, J.R. 2014. Diagnostic accuracy and clinical utility of biopsy in musculoskeletal lesions: A comparison of fine-needle aspiration, core, and open biopsy techniques. Diagnostic Cytopathology 42(6): 476-486.

LeBoit, P.E. (Philip E); International Agency for Research on Cancer; World Health Organization; International Academy of Pathology; European Organization for Research on Treatment of Cancer; UniversitätsSpital Zürich Departement Pathologie. 2006. Pathology and Genetics of Skin Tumours. Lyon: IARC Press pp. 9-291. 
Lee, E.H., Nehal, K.S. \& Disa, J.J. 2010. Benign and premalignant skin lesions. Plastic and Reconstructive Surgery 125(5): 188e-198e.

Luba, M.C., Bangs, S.A., Mohler, A.M. \& Stulberg, D.L. 2003. Common benign skin tumors. American Family Physician 67(4): 729-738.

Mohammedamin, R.S., van der Wouden, J.C., Koning, S., van der Linden, M.W., Schellevis, F.G., van Suijlekom-Smit, L.W. \& Koes, B.W. 2006. Increasing incidence of skin disorders in children? A comparison between 1987 and 2001. BMC Dermatology 6: 4.

Murray, C.J., Lopez, A.D., Black, R., Mathers, C.D., Shibuya, K., Ezzati, M., Salomon, J.A., Michaud, C.M., Walker, N. \& Vos, T. 2007. Global burden of disease 2005: Call for collaborators. Lancet 370(9582): 109-110.

Nguyen, T. \& Zuniga, R. 2013. Skin conditions: Benign nodular skin lesions._FP Essentials 407: 24-30.

Pujani, M., Madaan, G., Jairajpuri, Z., Jetley, S., Hassan, M. \& Khan, S. 2016. Adnexal tumors of skin: An experience at a tertiary care center at Delhi. Annals of Medical and Health Sciences Research 6(5): 280-285.

Sinikumpu, S-P., Huilaja, L., Jokelainen, J., Koiranen, M., Auvinen, J., Hägg, P.M., Wikström, E., Timonen, M. \& Tasanen, K. 2014. High prevalence of skin diseases and need for treatment in a middle aged population. A Northern Finland Birth Cohort 1966 Study. PLoS ONE 9(6):e99533.
Wakely, P.E. Jr. \& Kneisl, J.S. 2000. Soft tissue aspiration cytopathology. Cancer 90(5): 292-298.

Woon, D.T.S \& Serpell, J.W. 2008. Preoperative core biopsy of soft-tissue tumours facilitates their surgical management: A 10 year update. ANZ Journal of Surgery 78(11): 977-981.

Sabahattin Destek*

Department of General Surgery

Bezmialem Vakıf University School of Medicine

34093 Fatih, Istanbul

Turkey

Vahit Onur Gul

Department of General Surgery

Gulhane Education and Research Hospital

06010 Etlik, Ankara

Turkey

*Corresponding author; email: dr.s.destek@gmail.com

Received: 13 February 2019

Accepted: 23 September 2019 